\title{
Social Structure as the Root of Improving Criminality in the Era of Pandemic Covid-19
}

\author{
Nur Khalimatus Sa'diyah* and Umi Enggarsasi
}

Faculty of Law Wijaya Kusuma Surabaya University, Indonesia

\begin{abstract}
A level in society which is a social structure or patterns that foster community life that has a role in an organization in a group. In the face of the Covid-19 Pandemic, the Middle Class and Lower Class Communities were greatly affected by their social and economic conditions, this has become a problem for the Increase of Crime in the era of the Covid-19 Pandemic. The problems in this study are First, what are the factors causing the social structure as the root of the increase in crime in the Covid-19 pandemic era. Second, how to deal with the increase in crime in the era of the Covid-19 pandemic. The research method used is juridical empirical, using primary and secondary data, and qualitative analysis presented descriptively. The result of this research is that with the existence of a social structure as the cause of crime that occurred during the Pandemic, the government must immediately find a solution and overcome it so that the crime rate can suppress and decrease.
\end{abstract}

Keywords: Social Structure, Crime, Covid-19 Pandemic.

\section{INTRODUCTION}

At the beginning of 2020 the whole world was being hit by an outbreak, namely the Corona Virus (Covid19), which was originally discovered and detected from Wuhan-China. In Indonesia, it was first confirmed that there was a positive infection with the Corona virus in early March 2020. This year is a year of crisis and worrying for all countries in the world due to the Covid 19 pandemic (Phan, Nguyen, \& al, 2020). The Covid 19 virus is a new disease that has a relatively fast transmission rate and a high mortality rate (Susilo \& et al., 2020). Therefore, the Covid 19 virus cannot be considered a trivial disease even though in 1960, the Covid 19 virus was considered the cause of the common cold (Al-Osail \& Al-Wazzah, 2017). Until now, no definitive therapy has been found to treat this virus (Whitworth, 2020). With the increasing number of people infected with the Corona virus, several regions in Indonesia have implemented Large-Scale Social Restrictions (PSBB) to suppress the positive number of the Corona Virus.

The PSBB policy that was taken for the first time by the Governor of Jakarta in order to prevent the spread of the Corona Virus which was eventually followed by several other regions in Indonesia turned out to have both positive and negative sides. The positive side of implementing the PSBB is the prevention of the spread of the Corona Virus, but on the other hand, it turns out that there is also a negative side to the impact of implementing the PSBB. Where with this policy, people

*Address correspondence to this author at the Faculty of Law Wijaya Kusuma Surabaya University Dukuh Kupang XXV / 54 Surabaya, Jawa Timur 60225, Indonesia; Tel: +62 031-5677577, +628179307356;

E-mail: nurkhalimatussakdiyah@gmail.com experience social restrictions, including studying, working and worshiping from home.

The concrete steps taken by the government are PSBB or social distancing which the Government will do next is to dismiss students, students and workers and replace them with studying from home, working from home, and worshiping at home. Although this activity cannot be interpreted as unlimited freedom (Abidah \& et al., 2020). The recommendation to carry out social distancing is carried out because the government understands that the spread of the Covid 19 virus is droplet from a splash when coughing or sneezing because it has flu-like symptoms and respiratory infections (Mijnes \& et al., 2004). So that the government then gave an appeal to all people to use masks in sick and healthy conditions. This is done to avoid the peak of the epidemic that can overwhelm health services, so that the number of positive cases of Covid 19 does not far exceed the existing health care capacity (Hollingsworth, Klinkenberg, \& Anderson, 2011).

Indonesia is one of the countries that has not implemented a national quarantine for the community in the face of this pandemic. One of the reasons is the study of economic problems that must be considered carefully. The government did not lock down, but the way the government responded to this situation was by issuing policies that were deemed capable of stabilizing the economy. The rational reasoning used by the government is of course legitimate as a rational decision-making process.

Basically, the regional quarantine policy is regulated in Law Number 6 of 2018 concerning Health 
Quarantine. Article 9 states that quarantine is carried out with the aim of protecting the community from disease and / or other causes of public health risk. In the quarantine policy, the Central Government and Local Governments will ensure that the community remains healthy and is responsible for meeting community needs. Lockdown and social distancing policies can be the right solution to deal with the Covid 19 virus (Mukharom \& Aravik, 2020). Because this policy is considered to be able to minimize the spread of the Covid 19 virus (Yunus \& Rezki, 2020). However, in fact, not all of them have the same perception and reason in seeing the policies for handling Covid 19 in Indonesia, so some are obedient and many are not.

As a result of the policies taken by the government in dealing with Covid 19, thus the economic turnover in Indonesia was very disturbed and caused many people to be laid off (Termination of Employment Relations), after which new problems arose in society, namely there were differences in socio-economic terms and levels. social structures in society that have resulted in an increase in crime, the perpetrators of which are many of the people affected in the economy due to Covid 19. The formulation of the problem in this study are Why is Social Structure the Cause of Increased Crime in the Covid 19 Pandemic Era and How to Prevent and Overcome the Increasing Crime in the Covid 19 pandemic era.

\section{RESEARCH METHOD}

The research method used is juridical empirical, using primary and secondary data, and qualitative analysis presented descriptively. Research with the title and problems above is a juridical empirical research, considering that the discussion is based on statutory regulations and related field data. In the discussion of problem formulations in number one and two, a conceptual approach and a statutory rule approach are used and field studies are also carried out to find and analyze why Social Structure is the cause of the Increase in Crime in the Covid-19 Pandemic Era, as well as about efforts to prevent and overcome crime in The Covid-19 Pandemic Era.

\subsection{Research Analysis}

This research aims to study the theory of subcultural delinquency is a theory that underlies this research. According to this theory, evil behavior is the characteristics of social structures with cultural patterns that are typical of the environment and society experienced by criminals. This happens because of the dense population, the low socio-economic status of the residents, the very poor physical conditions of the village, or also because of many familiar and high-level social disorganizations. This factor can be a factor causing the occurrence of crime, the purpose of this factor is that the cause of crime is seen based on the location of a certain area where a crime occurs. In this case this factor is located outside of the perpetrator of the crime. Usually urban areas will be more vulnerable than in rural areas to the occurrence of a crime, for example crimes against property, theft or robbery, this happens because usually people who live in urban areas will think about social strata rather than their own security, by having a consumptive lifestyle and tend to wasting money. During the Covid 19 Pandemic, with the increasing crime that occurred in Indonesia, one of the contributing factors was the existence of social inequality / social structure in society as a result of an increasingly difficult economy.

\subsection{Research Purpose}

For researchers, this is to study why the reason of Social Structure the Cause of Increased Crime in the Covid 19 Pandemic Era. Because by study it, we can analyze how to Prevent and Overcome the Increasing Crime in the Covid 19 pandemic era.

\section{RESULTS AND ANALYSIS}

\subsection{The Functions of the Social Structures that Exist in Society are}

a. Establishing Social Order, meaning that with a clear social structure within the organization or community life all patterns and community actions will be regulated according to the applicable agreement.

b. Make it easier to achieve goals, social structures that exist in society can directly facilitate the desired goals. This goal of course will not be achieved if there is no mutual commitment between the community.

c. Creating the Order of Life, the function of transience with the existing social structures in society is to create the order of life. A life order that goes well will create harmony and peace in people's lives.

Social Change and Cultural Change According to Harper, social change is defined as a significant 
change (change) regarding the social structure within a certain period of time. Changes in this structure contain several types of changes in social structure, namely First changes in the personal associated with changes in roles in new individuals in the history of human life related to the existence of structures. Second, changes in the way the parts of the social structure relate. This change, for example, occurred in a change in the work flow of the bureaucracy in government institutions. Third, changes in the functioning of the structure are related to what society does and how that society does it. Fourth, changes in the relationship of different structures. Fifth, the emergence of a new structure which is an event for the emergence of a new structure to replace the previous structure (Nanang, 2011: 5).

According to Himes and Moore, social change has three dimensions, namely structural, cultural and interactional dimensions. First, the structural dimension refers to changes in the structure of society, involving changes in roles, emergence of new roles, changes in social class structures, and changes in social institutions. The two cultural dimensions refer to cultural changes in society. These changes include innovation, diffusion, integration. The three interactional dimensions refer to changes in social relations in society (Nanang, 2011: 5).

The large number of unemployed in an area, generally in Indonesia, due to the impact of the Covid 19 pandemic is a problem that does not only cover the economic sector, the problem of unemployment is also closely related to the social sector. In this day and age, not only people with low financial backgrounds are unemployed, but people with good financial backgrounds are still unemployed. Brush (2007) found that high-income individuals were significantly correlated with crime, even though these individuals were categorized as unemployed. The behavior of people who naturally do not have a sense of satisfaction with something they have is able to push themselves to do anything. Every economy does not always achieve a state of full empolyment and strong economic growth, resulting in economic problems.

Criminal acts are caused by people who fall into the productive category but are not currently working or are unemployed. Unemployment is a condition where people do not have a job and are looking for work (Adioetomo, 2010). When an individual is unemployed for a longer period of time, the opportunity to commit a criminal act will be higher (Bender, 2016). Meanwhile, the impact of the Covid 19 pandemic is that many people fall into the productive category but they are terminated and become unemployed.

Anata revealed that the effect of the unemployment rate on the crime rate has a significant effect (Anata, 2013). (Becker, Journal, Apr, \& Becker, 2005) states that unemployment is positively related to crime because when individuals are unemployed, their productive time is not used in activities that generate money. (Buonanno \& Vargas, 2019) conducted a study on the crime rate and the unemployment rate, the results of the research were that the unemployment rate positively influenced criminal acts, and could become a habit of acting in violation of the law. Unemployment can lead to social and political instability, sluggish economic activity and high unemployment will encourage criminal activities such as theft and piracy (Sukirno, 2000).

\subsection{The Effect of Poverty on Crime}

Poverty is also not a new phenomenon in the social life and life of every country. The National Development Planning Agency (BAPPENAS) states that poverty is a condition and is a situation of deprivation due to conditions that cannot be avoided by a person or individual with the power that is within him or his strength. Poverty is also a social phenomenon and a condition that has always been the attributes of third world countries. This phenomenon is the opposite of a condition experienced by developed countries where developed countries have the attributes of a modern country. If observed, it is as if poverty is an identical condition and is always inherent in the structure of third world countries and has become a serious enough problem to get the handling of state administrators.

Poverty itself can be interpreted as follows: "lack of an ability to meet basic needs for survival". The point of this poverty is the form of a person's inability to get a decent life. Poverty can also be defined as a low standard of living for the community, namely the existence of a level of material shortage in a number of people or a group of people compared to the standard of living that generally applies to the life of the community concerned.

Thus, those who are and live below the poverty line have the following characteristics:

a. Not being able to have their own production factors such as land, capital and lack of skills.

b. Does not have the possibility to acquire and own production assets with one's own strength such 
as obtaining cultivated land or obtaining business capital.

c. The level of education they have is low, even their education does not complete primary school because they have to earn income compared to school.

d. Most of those who live below the poverty line live in the village as self-employed, trying whatever they can without looking at skills.

e. Many of those below the poverty line live in cities and are young and unskilled.

Criminal acts are dominated by poor people who are unable to meet their living expenses (Mehlum, Miguel, \& Torvik, 2006). Research conducted in Malaysia by (Tang, 2015) shows that there is a positive and significant effect in the long and short term, regarding the existence of poverty greatly influences crime. The fact is that individuals who are under the pressure of living in deprivation or in this case are poor people, encourage them to commit acts of theft, so that the increasing or growing poverty rate encourages someone to commit criminal acts. In accordance with the theoretical model built by finding a relationship between conditions of worsening poverty or in the sense that increasing poverty causes an increase in immorality, especially in the act of robbery (Mehanna, 2004) observed that the poverty rate has a positive effect on increasing crime. Someone who lives below the poverty line is more likely to commit illegal acts because they don't get the attention of normal people who take legal actions.

The active role of the community in social welfare development will be one of the determining factors for success, and social welfare efforts are the joint responsibility of the government and society. Poverty is defined as a condition in which a person is unable to maintain himself in accordance with the standard of life of the group and is also unable to utilize mental and physical energy in the group. Poverty is another for those who participate in urbanization but fail to find work. For them, the main problem of poverty is due to not being able to meet primary needs, resulting in unemployment, homelessness and so on. Sociologically, the causes of the problem are because one of the social institutions is not functioning properly, namely the social institution in the economic field. A poor family (underprivileged) is a family that has not fulfilled one or more of the following requirements: 1.
Can eat two or more times a day 2. Have different clothes for various purposes 3 . The floor of the house is not land 4. If the child is sick, he is taken to a facility for treatment. / to the puskesmas According to Parsudi Suparlan says poverty is a low standard of living, that is, there is a level of material deficiency in a number or a group of people compared to the standard of living generally prevailing in the community concerned. Thus, basically poverty refers to a state of lack of fulfillment of a number of needs, such as clothing, food, shelter, employment, education and knowledge.

According to the law, crime is a human act that violates or is contrary to what is stipulated in the rule of law; explicitly acts that violate the prohibitions stipulated in the rule of law, and do not fulfill or violate the orders that have been stipulated in the rules of law applicable in the community concerned resides.

Crime also occurs due to unemployment, among others:

a. The welfare level decreases.

b. The number of crimes (crimes) has increased, for example theft, mugging and mugging.

c. Decreased quality of life, characterized by a dirty (unhealthy) environment.

d. The productivity of the community has decreased, causing poverty.

e. Decreased levels of health and food shortages.

f. An increase in the number of street children, homeless people, buskers in public places, and so on.

g. Decreased state income from income tax revenues. h. Increased state social costs.

\subsection{Crime Factors during the Covid Pandemic 19 Viewed from a Criminological Perspective}

Related to the factors of crime during the COVID-19 pandemic, it can be seen from the perspective of criminology and victimology. Criminology is a science that studies crime, where one of the discussions is about the etiology of crime (Susanto, 2011), in the view of criminology there are 4 (four) factors that encourage perpetrators to commit criminal acts.

First, economic factors, W.A. Bonger as a criminologist expresses the view that what is meant by 
economic factors is the strongest motivating factor for someone to commit a crime, adding that what he calls "Subjective Nahrungschwerung" (unemployment) is also something that encourages crime during a pandemic as well as large-scale activity restrictions to prevent The spread of the corona virus has an impact on decreasing people's livelihoods (Susanto, 2011). The occurrence of layoffs due to this pandemic causes those who are laid off victims will find it difficult to fulfill their daily needs (Romlah, 2020). stealing, cheating, robbing, etc. This shows that economic factors are the main and dominant motivation for perpetrators to commit crimes during a pandemic.

Second, the perpetrator's social environment. M. Torttier in his study stated that "in a crime committed by a small group (2-4 people) is a description of the personality of each individual, although in a joint decision it can be different if it is only faced alone, this is that the group can commit crimes., but if only one member may be able to refrain from doing so "(Susanto, 2011). Several crimes during the COVID-19 pandemic were carried out in groups, where the perpetrators had their respective job descriptions in carrying out the action. Therefore, the social environment of the groups that is formed encourages individual behavior in making decisions to commit crimes during the COVID-19 pandemic. Crimes committed by individual perpetrators are also inseparable from the influence of the social environment. In the case of crime during the COVID-19 pandemic, the factor that drives the perpetrator is himself, who is still young, so the desire to live "hedonistically, spree from the proceeds of crime". Referring to this, if the perpetrator is in a good social environment, the environment will be more able to bind the potential perpetrator to not having this lifestyle, so that the potential perpetrator does not commit crimes (Ediwarman, 2012).

Third, a place where the crime is possible even when the victim gives the opportunity, but a place where it is not possible to commit a crime, the perpetrator can stop his intention to commit a crime. In connection with crime during the COVID-19 pandemic, it shows that several cases of crime occurred in quiet areas and could be identified as crime-prone areas. However, on the other hand, several crime cases during the COVID-19 pandemic actually occurred in busy areas. This shows that the occurrence of robbery crimes does not depend on lonely or crowded places, but rather on a place where the perpetrator can commit crimes. The phenomenon of criminals committing their actions in crowded areas is explained by "ecological theory, one of which is population mobility. Population mobility here refers to horizontal mobility, which in recent times has clearly seen an increase. This is mainly due to the increasing influence of transportation facilities. According to McKay, based on the results of his research, he said that the highest crime rates were in the industrial and trade centers, the poorest areas, areas inhabited by emigrants and negroes. Based on this ecological theory, several cases where crimes occurred during the COVID-19 pandemic occurred in urban areas. The urban area here is synonymous with the center of trade, thus affecting population mobility, thus becoming a target place for criminals. This is also reinforced in the Victimology study "that in business areas in the suburbs of the city, and in small city business areas where there are valuable assets, the criminal act of theft with violence is very dominant. Including, there is a tendency to be at risk of becoming victims of criminal acts of violence on public roads. This is due to the consideration that the perpetrators have an easier chance of escaping than on small roads "(Angkasa and Iswanto, 2009).

Fourth, imitating crimes in other areas (including the role of the media). One of the criminal theories states the theory of "Differential Association" (Dj Sophisticated and Nurul, 2018) which is based on the learning process, namely that "criminal behavior is learned behavior". This means that someone who commits a criminal act is caused by the process of imitating or learning from other people who have committed the crime. According to Sutherland, "if criminal behavior is studied, what is learned includes (a) techniques for committing crimes (b) certain motives, encouragement, justification and attitudes" (I.S Susanto, 2011). Thus, one of the prepositions states "that non-personal communication, such as through cinemas, newspapers, relatively does not have an important role in the occurrence of criminal behavior". This view is inversely proportional to wealth in society, one of which is the existence of imitation, due to crimes such as the seizure of mini-markets, hoarding masks in other areas, including the role of the mass media in intensively reporting crime cases during the COVID-19 pandemic. . This is as according to members of the National Police, that "there may be an influence from the role of the mass media which can have a positive impact on society, but sometimes negatively for the perpetrators, namely adding information about crimes, especially for beginners". 


\subsection{Crime in the Covid-19 Pandemic Era}

An increase of $11.80 \%$ of the crimes occurred in the 15 th week and 16 th week of 2020 . There were 4244 cases of corruption in the 23 rd week of 2020 . These cases have an increase of $38.45 \%$ so that there were 5876 cases in week 24.

The highest increase was in gambling cases, and we're at week 23, which had an increase in week 24 , it doubled to 104 cases. Meanwhile, motor vehicle theft cases also increased by $98.25 \%$ from 114 cases to 226 cases in week 24. Meanwhile, cases of theft with weighted increased by $68.61 \%$, from 411 cases to 693 cases. Meanwhile, there was 126 embezzlement to 421 or an increase of 42.71 instances.

Meanwhile, in the 34th week in July 2020 , there was an increase of $7.08 \%$ from 5282 cases to 5656 cases. Meanwhile, in week 35, which was not August 2020, there was also an increase of $4.49 \%$, from 4449 to 4649 cases. Week 36 , there are 4571 cases, while week 37 increases to 5354 cases. However, to see whether the rise in crime is related to the spread of Covid-19 in Indonesia or not, of course, research is necessary first.

Tackling and handling the spread of Covid-19 in Indonesia positively impacts both formal and informal workers. With the large-scale limitation program implemented for handling Covid-19, of course, it has an impact on the community. This program limits mass gathering activities by the community so that there are no more activities that are mass gathering, such as worship activities, studying, and even doing work. Done from home or known as Work From Home (WFH).

Of course, it causes losses to businesses that focus on mass associations, such as shops, restaurants, depots, schools, universities, and other educational institutions. Failures in these businesses will undoubtedly impact the termination (PHK) for employees because there are no benefits due to customers' absence. The impact is also felt by people who rely on their livelihoods with daily income, such as selling food or other goods.

Termination of employment and the absence of income from people who work daily have caused the community's economy to experience a decline or even none at all. It causes them to think of ways to meet their economy's needs, causing them to do everything they can to fulfill them, even by committing crimes.
The impact of another pandemic that has also occurred is that due to a declining economy, in the end, many children of school age drop out of school, leaving them vulnerable to commit crimes. Release of prisoners to reduce the impact of Covid-19 also further increased the crime. That occurred because of the 38822 prisoners released due to the assimilation of Covid-19, 13 prisoners repeated their crimes.

The economy is one of the reasons for the increase in the number of crimes. It can be seen from the data received that the most frequent cases were theft cases with a weighting of 605 cases. Followed by embezzlement as many as 380 cases and followed by theft of motor vehicles totaling 246 cases, theft with violence as many as 103 cases, and 54 cases of rape followed.

The data above states that the crimes that occurred most frequently during the pandemic were theft, embezzlement, motor vehicle theft, and violent theft. Of course, all of these crimes are related to the perpetrator's desire to obtain assets from the victim and gambling, which is also the desire of the perpetrator to increase his wealth.

The fear of the Covid-19 pandemic, which causes people to prefer to buy goods from home online, causes the situation to be quieter than before, thus providing an opportunity for criminals to commit crimes. The crime data can be seen, which also experienced an increase, namely rape as many as 54 cases. The theft in the minimart has also increased because the minimart was initially open 24 hours non-stop, so this time it can only be open until $10 \mathrm{pm}$ so that criminals can use it to steal the minimart.

\subsection{Crime Prevention and Eradication Efforts in the Covid-19 Pandemic Era}

Crime prevention is essentially an integral part of social defense efforts and efforts to achieve social welfare. After we know the causes of crime, then we must know what countermeasures must be done. Crime prevention is a variety of proactive and reactive activities directed at both the perpetrator and the victim, and in the social and physical environment, which are carried out before or after a crime occurs. Therefore, the ultimate goal or main objective of overcoming crime is the protection of society in order to achieve social welfare. As for providing protection for the community related to crimes during the COVID-19 pandemic, one of which is through the duties and functions of the 
Indonesian Police. Pursuant to Article 13 of Law Number 2 of 2002 concerning the Indonesian National Police (Police Law), the main duties of the State Police of the Republic of Indonesia are: (1) maintaining security and public order; (2) enforcing the law; and (3) provide protection, protection, and services to the community. The remaining duties are regulated in Article 14 of the Police Law. In connection with the duties and functions of the National Police, according to Awaloeddin Jamin that in practice in the field, the Police call this preemptive term "community development" or "indirect preventive", namely guidance aimed at making people become law abiding citizens.

There are three ways of handling that can be done against crime, namely, pre-emptive, preventive and repressive.

\section{a. Pre-Emtive}

Pre-emptive are the initial efforts made by the police to prevent crime from occurring. The efforts made in preventing crime pre-emptively are instilling good values and norms so that these norms are internalized in each person. someone. Even if there is an opportunity to commit a crime, but there is no intention to do so, there will be no crime. Thus, in pre-emptive efforts the intention factor is lost despite the opportunity. In this pre-emptive countermeasure the Police as law enforcers shall prevent the occurrence of motor vehicle theft crimes by providing an understanding of the importance of obeying the applicable law.

Other related parties who can be the parties to tackle at this stage are religious figures or scholars, ulama can provide insights to the community about religious law if they commit a crime, or by providing moral lessons for the community. Apart from the police and ulama, the parties also making this effort are the mass media, mass media, both printed and electronic, can prevent crime by providing massive coverage of the occurrence of crimes that are rife and the impacts they have had on a continuous basis, thus forming a community culture. which does not compromise any form of crime. With this effort, the community is expected to be able to better comply with all existing regulations so as not to commit any type of crime, including motor vehicle theft crimes that are rife. The government has a responsibility in efforts to combat crime, efforts that can be made are through influencing the pattern of people's lives through systematic efforts to build public awareness of the consequences of criminal acts and the impact of punishment. For example, a convicted person will be limited in his political rights for several years after completing several years of serving his sentence. Other parties who can also tackle crime through pre-emptive efforts are community leaders. Community leaders can influence the surrounding community through efforts to awaken their spiritual soul. Although these activities have been carried out frequently, such activities should be seen as necessary as an effort to raise awareness of the dangers of crime against oneself, family and society. Meanwhile, other efforts that can be done by other parties, namely educators, are revitalizing and reactualizing character education, intervention education and habituation education, and building awareness of moral intelligence and values (M. Ali Zaidan, 2016)

As for Pre-emptive crime prevention efforts:

1. From the function of Bimas (Community Guidance and Counseling), Sabara, and polsekrelated crimes;

2. Serving and serving program, namely by means of a KAMTIBMAS safari (Community Order Security) to community leaders and village officials;

3. Community development through Polmas (activating Polmas);

4. Cooperating with the mass media to convey to the public to always be aware of crime.

\section{b. Preventive}

These preventive measures are a follow-up to preemptive efforts which are still in the prevention stage before the occurrence of crimes. The emphasis on preventive measures is to eliminate opportunities to commit crimes. Preventing crime is better than educating criminals to be better again, as the motto in criminology is that efforts to correct criminals need to be considered and directed so that repeat crimes do not occur. The police in this effort provide legal education related to crime and provide lessons on legal arrangements related to crime. So that it can minimize the perpetrators of committing crimes. In addition, the police provide information to the public about actions that can lead to crime, for example the community must be careful in placing their motorized vehicles and also reduce passing streets that are quiet, roads that are damaged and lacking lighting. Recognizing that there will be needs to develop social drives or social 
pressures and economic pressures that can influence a person's behavior towards evil deeds. Furthermore, it focuses attention on individuals who show criminal or social potential, even if the potential is caused by biological or psychological disorders or lack of sufficient socio-economic opportunities so that they can form a harmonious whole. After looking at this description, we will know that crime can be tackled if the economic or social conditions that affect a person towards criminal behavior can be returned to a good direction. In other words, there must be improvement in economic factors. Meanwhile, biological, psychological, and social are only secondary factors. Then the community also has an important role in this prevention stage, the community can do things that can prevent the occurrence of crime by minimizing the occurrence of crime through efforts, for example, the environmental security system (siskamling), by doing this at least the community makes efforts to prevent crime in neighborhood around the residence.

Efforts to tackle crime or preventive action are usually carried out by two methods, namely the moralistic method and the abolitionistic method. Moralism is done by fostering mental spirituality that can be done by scholars, educators, and so on. Meanwhile, the abolitionistic method is a conceptual method of countermeasures that must be planned on the basis of criminological research, and explore the causes of various interrelated factors. The most common way this is done is by integrating various elements related to the criminal justice mechanism and community participation. To strengthen the operational capacity of the countermeasures, it is necessary to combine 3 wills; political will, social will and individual will. The will of the government (pollitical will) with various efforts needs to be supported by a social image (social will) through various media to launch the will of the government, and a force that should not be forgotten is human or individual will, in the form of awareness to obey / obey the law and always try to avoid oneself. not to do evil. (Abintoro Prakoso, 2013).

The right effort to integrate the three desires is by means of: Increasing and stabilizing the law enforcement apparatus including strengthening the organization, personnel, and infrastructure for the settlement of criminal cases. 2. Legislation that can function to canalize and stem crime with a reach into the future. 3. An effective criminal justice mechanism that meets the requirements is fast, precise, cheap and simple. 4. Coordination between law enforcement officers and related government officials, to increase efficiency and effectiveness in overcoming crime. 5 . Community participation to help smooth the implementation of crime prevention.

Preventive crime prevention efforts:

1. Strong points in vulnerable areas from both Polres and Polsek;

2. Carry out routine operations;

3. Informant Approach and Dissemination;

4. Approach to recidivists.

\section{c. Repressive}

This effort is made when a crime has occurred, the action of which is law enforcement by imposing a sentence. The prevention that is done is by taking action against the perpetrators of crimes according to their actions and correcting them again so that they are aware that their actions are illegal and detrimental to society. This effort can also be accompanied by fairly decisive actions from law enforcers, especially the Police, in the form of physical contact or by using firearms, if the situation is urgent to use them, this is done in order to provide a deterrent effect to every criminal, so as not to commit another crime. . In the case of the use of firearms and physical contact, it is true that the Police are allowed in certain circumstances, for example the perpetrator tries to escape during the arrest process, the perpetrator has a sharp weapon or firearm, and also if the perpetrator tries to resist the Police. This repressive effort is the last resort that must be done, because this effort has the character of providing lessons to the perpetrators of crimes not to repeat their actions, even though this effort seems to be an effort to provide a deterrent effect. If the prosecution efforts carried out by law enforcers have gone well, it is hoped that the occurrence of further crimes can be tackled. It is hoped that the enforcement of good crimes will have a deterrent effect on every criminal. Efforts started from investigations, continued with investigations, prosecutions, trial examinations in court, and the sentence was determined by the judge (M. Ali Zaidan: 2016)

As for the efforts to overcome repressive crimes:

1. Arrest the perpetrator and process it in accordance with applicable legal procedures;

2. Direct guidance during personal investigation of the perpetrator; 


\section{Eradicating crooks;}

4. Firm attitude towards the perpetrator.

As for the assertive attitude towards the perpetrator, that is, if the public is disturbed and against the officer, a shoot is carried out in accordance with the SOP. tasked with mapping areas prone to the spread of the corona virus as a preventive measure, the police conducted patrols in areas prone to the spread of the virus, carried out surveillance such as measuring body temperature, and spraying public places with disinfectant liquid, the Police appealed to the public to keep their distance and practice clean life. The police are tasked with cracking down on perpetrators of crime, for example hoarders of staple goods, The police are also in charge of preparing isolation rooms for patients infected with the corona virus, preparing health facilities and officers, to provide assistance to the families of suspected coronavirus patients. When a crime occurs, the National Police does not hesitate to take firm action against the perpetrator of the crime. This is done to provide assurance to the community and reduce the space for criminals to move. Criminals take advantage of the situation when all focus on handling and overcoming the spread of COVID-19. The National Police makes efforts to address the factors that cause and motivate people to commit crimes with guidance and counseling to use time at home (work from home). Preventive activities were also carried out after analysis and evaluation (ANEV) that they carried out there was an increase in the number of crimes by actively patrolling and guards in places prone to crime. Law enforcement by means of exposing crimes that have occurred is also continuously carried out by the Criminal Investigation Unit, including maintaining stability and availability of basic necessities for the community. In dealing with crimes, especially cases of theft, which have increased to deal with all of this, firstly, our regional police command orders to map, where high criminals, such as dismantling minimarkets, begging, hoaxes first map each area by the ranks of the police. The National Police has also issued Telegram Letter Number ST / 1238 / IV / OPS.2 / 2020. The contents are intended for Kasatgaspus, Kasubsatgaspus, Kaopsda, Kasatgasda, Kaopsres, and Kasatgasres to put forward preemptive and preventive efforts in an effort to reduce the crime rate. The police will not hesitate to take firm and measurable action against every criminal, such as robbery, theft, mugging, thuggery, to brawls. The National Police has carried out a mapping of the criminal groups. Including, increasing regional patrol activities to create security and public order.

\section{CONCLUSION}

The pandemic period causes a change in the social structure that causes an increase in crime. The government must immediately get a solution and overcome it. The crime rate can be suppressed and decreased appropriately by using preventive means by monitoring individuals who are deemed capable of committing crime or socialization or legal counselling or repressive nature with law enforcement.

\section{REFERENCES}

Abidah, A., \& dkk. (2020). The Impact of Covid 19 to Indonesian Education and Its Relation to the Philosophy of "Merdeka Belajar". Studies in Philosophy of Science and Education 1 (1)

https://doi.org/10.46627/sipose.v1i1.9

Adioetomo, S.M, dkk. (2010). Dasar-Dasar Demografi Edisi 2. Jakarta: Salemba Empat.

Al-Osail, A. M., \& Al-Wazzah, M. J. (2017). The history and epidemiology of Middle East Respiratory Syndrome Corona Virus. Multidisciplinary Respiratory Medicine. https://doi.org/10.4081/mrm.2017.246

Anata, F. (2013). Pengaruh Tingkat Pengangguran Terbuka, Pdrb Perkapita, Jumlah Penduduk Dan Index Williamson Terhadap Tingkat Kriminalitas (Studi Pada 31 Provinsi Di Indonesia Tahun 2007-2012).

Angkasa dan Iswanto. (2009.) Viktimologi, Buku Ajar, FH Universitas Jenderal Soedirman, Purwokerto.

Becker, G. S., Journal, T., Apr, N. M., \& Becker, G. S. (2005). Crime and Punishment: An Economic Approach. 76(2). https://doi.org/10.1086/259394

Bender, K. (2016). Economic fluctuations and crime: temporary and persistent effects. Journal of Economic Studies, 43(99990000084826), 609-623. https://doi.org/10.1108/JES-05-2015-0085

Buonanno, P., \& Vargas, J. F. (2019). Inequality, crime, and the long run legacy of slavery. Journal of Economic Behavior and Organization, 159, 539-552. https://doi.org/10.1016/j.jebo.2017.12.022

Djanggih, H. and Qamar, N. (2018). Penerapan Teori-Teori Kriminologi dalam Penanggulangan Kejahatan Siber (Cyber Crime), Pandecta: Jurnal Penelitian IImu Hukum (Research Law Journal), 13(1). https://doi.org/10.15294/pandecta.v13i1.14020

Hollingsworth, T., Klinkenberg, D., \& Anderson, H. H. (2011). Mitigation strategies for pandemic influenza A: Balancing conflicting policy objectives. Plos Comput Biol 7 (e1001076). https://doi.org/10.1371/journal.pcbi.1001076

M. Ali Zaidan. (2016). Kebijakan Kriminal. Sinar Grafika. Jakarta.

Mehanna, R. (2004). Poverty and economic development : not as direct as it may seem. 33, 217-228. https://doi.org/10.1016/j.socec.2003.12.013

Mehlum, H., Miguel, E., \& Torvik, R. (2006). Poverty and crime in 19th century Germany. Journal of Urban Economics, 59(3), 370-388. https://doi.org/10.1016/j.jue.2005.09.007

Mijnes, D. G., \& dkk. (2004). Natural History of a Recurrent Felline Coronavirus Infection and The Role of Cellular Immunity in Survival and Discase. Journal of Virology.

Mukharom, \& Aravik, H. (2020). Kebijakan Nabi Muhammad SAW Menangani Wabah Penyakit Menular dan Implementasinya dalam Konteks Menanggulangi Corona Virus Covid 19. Salam: Jurnal Sosial \& Budaya Syar'i 7 (3) https://doi.org/10.15408/sjsbs.v7i3.15096 
Nanang Martono. (2011). Sosiologi Perubahan Sosial, (Jakarta : Rajagrafindo Persada).

Phan, Nguyen, L., \& al, e. (2020). Importation and Human-to-human transmissionof a Novel Coronavirus in Vietnam. N Eng $\mathrm{J}$ med. https://doi.org/10.1056/NEJMc2001272

Sukirno, S. (2000). Makroekonomi Modern. Edisi ketiga. Jakarta: Rajawali Pers Tang, C. F. (2015). Penentu Makroekonomi Kadar Jenayah di Malaysia. 49(2). https://doi.org/10.17576/JEM-2015-4902-05

Susanto, I.S.. (2011). Kriminologi, Genda Publishing, Yogyakarta Ediwarman, 2012, Paradoks Penegakan Hukum Pidana
Dalam Perspektif Kriminologi di Indonesia, Jurnal Kriminologi Indonesia, 8 (1).

Susilo, A., \& dkk. (2020). Coronavirus Desease 2019: Tinjauan Literatur Terkini. Jurnal Penyakit Dalam Indonesia 7 (1). https://doi.org/10.7454/jpdi.v7i1.415

Whitworth, J. (2020). Covid 19: A Fast EvolvingPandemic. Trans R Soc Trop Med Hyg. https://doi.org/10.1093/trstmh/traa025

Yunus, N. R., \& Rezki, A. (2020). Kebijakan Pemberlakuan Lockdown sebagai Antisipasi Penyebaran Corona Virus Covid 19. Salam: Jurnal Sosial \& Budaya Syar'i 7 (3). https://doi.org/10.15408/sjsbs.v7i3.15083

Received on 17-05-2021

https://doi.org/10.6000/1929-4409.2021.10.140

(C) 2021 Sa'diyah* and Umi Enggarsasi; Licensee Lifescience Global.

This is an open access article licensed under the terms of the Creative Commons Attribution Non-Commercial License (http://creativecommons.org/licenses/by-nc/3.0/) which permits unrestricted, non-commercial use, distribution and reproduction in any medium, provided the work is properly cited. 